\title{
From Budgeting to Buying: Canadian Consumerism in the Post War Era
}

\section{Bettina Liverant}

From the late 1940s to the early 1960s Canadians shifted from a predilection for carefil budgeting and "making do" to consumers in training, and later, full-fledged participants in the buy now. pay later mode of North American consumption prevalent from the sixties to the present. Using three "typical" Canadian families featured by Chatelaine Magazine in 1949, 1954 and 1962 as the hub of analysis, this article examines the transformation in attitudes toward domestic spending. the use of credit, and the manner in which new patterns of spending and consumption were simultaneously reflected in and authorized by the magazine.'

We are commonly said to live in a consumer culture, but what does this mean and when did this happen? The postwar years have been identified by Canadian historians as the key era in the transformation from decades of scarcity and an ethic of "making do" to modern consumer practices of spending, credit, disposability and obsolescence. In the pages of Chatelaine, Saturday Night, Maclean's and other popular publications, the experts who stressed "learning to budget" during the years of depression and war began instead to emphasize "learning to buy." Personal jdentity came to depend less on what one made (whether in the home or the factory) and more on what one bought. Family roles were redefined and gender distinctions reconfigured around the axis of consumption. The ideal of the skilled and thrifty mother and wife yielded to a newer image of wife as household manager and purchasing agent, now in charge of 80 to $90 \%$ of the family expenditures. Over the same period, husbands were reduced from war heroes to wage earners; and children introduced to weekly allowances, ensuring that they to would grow up experienced in the moral and practical challenges of budgeting. And yet, new attitudes were accompanied by considerable pressure to conform and to maintain certain aspects of the status quo,

1 I am indetxed to the anonymous reviewen of Past foppeffect for their critical comments, dinection and worts of suppont offered on an earlier draft of this anticle.

Past Imperfect, Volume 8, 1999-2000 
particularly a commitment to family values and an ethic of personal responsibility.

The emphasis on consumer goods was balanced by messages to plan spending and keep expectations modest: a mortgaged home. a car (maybe second hand), labour saving devices bought on the installment plan, book clubs and record collections were presented as the substance of the average Canadian's dreams. By the 1960s rising incomes, the increasing availability of credit, and falling prices of certain staple items allowed middle income Canadians to participate more freely in the expanding world of consumer goods. Money management no longer meant self-denial; instead, it came to be seen as a matter of making choices and ordering priorities to ensure that each family was able to direct its income toward satisfying its needs and achieving its wants.

The bulk of this article will focus on three families selected by Chatelaine Magazine as the subject of articles in 1949, 1954, and 1962. All three accounts (entitled respectively "Rich on $\$ 40$ a Week", "We Sent an Expert to Help This Family Make Both Ends Meet", and "101 Ways to Save Money-and look better, dress better, eat better and live better") focused on domestic spending issues and described families with young children confronting the challenges of modern living with varying degrees of success. In their stories it is possible to see the image of the modern Canadian family take shape, increasingly constructed around the consumption of goods and services. The Menzies, featured in the early postwar period demonstrated by the strength of their personal example how to live modestly and make sacrifices with grace. By 1954, Chatelaine's "lypical" Canadian family was less competent. Portrayed as young and inexperienced, overwhelmed by impulsive spending and bad budgeting decisions, the Woods scemed unable to navigate the new world of consumer goods, installment buying and rising incomes. However, by following the advice of an expert provided by the magazine, this family learned how to budget, research and plan purchases to obtain whatever they wanted most. While the Woods 
needed only a period of tutelage under a single expert, the Roses (1962) required significant input from the staff of the Chatelaine Institute and a small team of additional consultants. The personal qualities of the Rose family fade into the background of the story, supplanted by the magazine's detailed recommendations for food, fashion, home decorating, and spending. Taken together, these articles reveal the formation of an ethos of consumption in the postwar decades, changes that were simultaneously reflected in and authorized by the magazine.

As Valerie Korinek has recently argued, Chatelaine offered a unique forum for the discussion and debate of modern living, marriage and motherhood during this era. ${ }^{2}$ Feminist oriented editors and writers received a considerable degree of leeway from the business department to challenge and even critique aspects of women's role in Canadian society as long as magazine sales remained strong. Readers-some intrigued, some in agreement and some in anger-discussed the issues of the day in letters to the editors and over coffee with friends. With a monthly readership of almost two million people from all regions of the country, rural as well as urban areas, and the middle as well as the working classes, Chatelaine addressed itself to a cross-section of the nation.

Korinek argues that the commercial imperatives of the publication, particularly the advertisements promoting household perfection through consumer spending, should be read separately from the feature articles, editorials and letters which, she contends, subversively complicated any simple recipe for affluent domesticity. In contrast, this article will suggest that the boundary between the world of goods and the world of feminist ideals was less firm than Korinek indicates. The writers at Chatelaine saw the exercise of freedom and choice in the selection and consumption of goods as well as in the discussion of birth control, divorce and racism.

The field of consumer culture as a whole is a relatively new one

2 Valerie Korinek. Roughing in in the Suburbs: Reculing Chusfaine Mugazine in the Fifries and Sluies (Tirosto: University of Toronto Press, 2000). 
in Canadian history. Key studies of the development of consumer society in the postwar era have been conducted by Joy Part and Doug Owram. ${ }^{3}$ Part focuses on the reductive and limiting aspects of the emerging culture of consumption, with a special emphasis on gender distinctions made between domestic work (labeled consumption) and industrial output (labeled production). Ultimately, Parr asserts that the gendering of consumption impoverished both realms, devalued domestic work and domestic needs while masking the wanton destruction of natural resources under the guise of industrial productivity.

What Parr sees as a time of lost potential, Owram sees as an cra of increasing prosperity and opportunity. Arguing that these years were in many ways revolutionary, he points to dramatic changes, particularly in housing and technology that made modern conveniences available to the average Canadian. If standardized production methods and demographic convergence resulted in an excess of conformity, they also created a unique sense of community and generational identity.

This study suggests that a fuller understanding of consumer culture must encompass and go beyond existing interpretations. Analysis of the Chatelaine stories reveals modest but steady increases in material prosperity, a partial relaxation of stringent selfdisciplines, and a certain encouragement to experiment, albeit in preapproved ways, in an expanding world of possibilities. At the same time, patterns of daily life and personal identity increasingly came to rest in goods and services that had to be purchased in the marketplace.

French cultural theorist Jean Baudrillard has observed that consumption "is a collective and active behaviour, a constraint, a morality, and an institution. It is a complete system of values, with

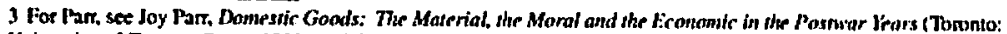
University of Tomnto Press, 1999) and Joy Pant and Gunilla Hiberg. "M/s Consumer and Mr. Keynes in fostwar Canada and Sweek" in Gesuler \& Wistory Vol. 8. No. 2. 1996. For Owram, see Doug Owrain, Borm al wir Right 7lme (Toronto: University of Toronto Press, 1996) and Doug Owram, "Canadian Ikonesticily in the Posiwar E:ra" in P. Neary and J.L_Granatstein (eds.). The Veterans Charter and Post. Hbrld War I/ Coushda (Montueal and Kingston: MeCill-Queen's Universily Press. 1998).
} 
all that the term implies concerning group integration and social control. Consumer society is ... the society for the apprenticeship of consumption, for the social indoctrination of consumption."4 These families were selected by Chatelaine and re-presented to the readers (and advertisers) as examples typical of the Canadian experience. By giving certain lifestyles tacit approval, and dispensing a range of money management advise instructing others how to achieve similar results, the magazine legitimized new patterns of spending and consumption and the partial reorganization of the family around the purchase of goods and services. By its nature this a limited rather than a comprehensive investigation, throwing open a window to reveal a glimpse of Canadian consumer society in its formative stages. However, by looking at the texture of changes presented in a medium often seen as a critical factor in the emergence of consumer culture, this exploration will help to shape a more complete understanding of postwar Canadian culture.

\section{The Context for Consumption}

By 1945 most Canadians, including the entire generation which had come of age during the late 1930s and early 1940s, could scarcely remember a time in which home life had not been threatened by depression or war. 5 These circumstances had taken a toll on both the Canadian psyche and on the material conditions of domestic life. The nation's housing stock was rundown and overcrowding was commonplace. 6 Goods were in short supply. For well over a decade Canadians had been guided by an ethic of making-do, played out against a backdrop of technological innovation and nationally advertised labour saving devices which promised easier lives for all even though few could afford them. ${ }^{7}$

4 Jean Baudrillanh "Consumer Sociely" in lawnence Glickman (ed.). Consumser Sociery in American Illstony: A Reculer (lltwaca: Comell Universily Press, 1999). p. 50.

5 Ouram, Canadizn Domesticity in the Postwar Eirs", p. 208

6 In 1939 aver one million Canadians wene estimated to live in nesidences with less than one room per person-a statislic that worsened during the war ycars then thousands moved from rural to untan areas to lake advantage of job onponunitles in the nation's expanding war industries. Ibid. p. 211.

7 As late as 1911 four out of five housctiolds silil nelied on icebuxes and nine out of ten used coal or wond stowes for leating. Flusl toilels were found in just over half of all Canadian homes, piped water in only six curs of ten. Ibut. p. 214. 
Although the booming wartime economy had finally put cash in the pockets of Canadians, opportunities to actually purchase goods remained linited as industrial production was directed to the war effort. Instead, Canadians were encouraged to examine their lives and do without. Magazines and newspapers touted the benefits of reduced consumption and celebrated the innovative reuse of timeworn possessions. ${ }^{8}$ Even as late as January 1945. when the war was drawing to a close and numerous restrictions had been removed, the needs and wants of the home front continued to take second place to war production. Addressing the housewife's desire for new appliances, Chatelaine offered a grim forecast for the year ahead: there would be no new electric or gas refrigerators; possibly 12,000 new electric ranges if material, parts and manpower permitted; a little less than half the normal output of coal and electric combination stoves; probably 30,000 washing machines or about one third of the normal output; no new sewing machines and no new radios. Production had begun on food mixers and the prospect was good for pots, pans, and heat proof glass utensils but not for "all the little things" like flour sifters, shakers, and graters made of tin or steel sheeting. 9

While the end of hostilities found the average Canadian family concerned with the practicalities of getting and spending, the government sought to steer a cautious course between depression (potentially caused by a slump in the economy as wartime industries closed down) and inflation (which might be induced by shortages). Most policy initiatives were directed toward bolstering large scale industrial efforts and increasing production for export, however various incentives were also devised to stimulate domestic consumption. Family allowances, for example, were seen not only as an aid to large families hurt by wage controls, but also as a means to "increase the buying power of those groups who not only need the money but who are most certain to use it immediately," as Health and Welfare Minister Brooke Claxton put it. ${ }^{10}$

8 Owran. Bom at the Right Tine, p. 70.

9 Chatelaine, January. 1945.

10 cited in Jances Siruthers, "Family Alkwances. OW Age Security. and the Constuction of Entitleneal in the Canadian Welfare State" in Neary and Granalucin. p. 18., 
Legislation aimed at solving the housing crisis similarly held out the promise of increased consumer spending. In 1944 the National Housing Act was rewritten, offering reduced interest rates and increased amortization periods to Canadians seeking first mortgages. Additional benefits directed towards the nation's veterans included even greater mortgage rate reductions, free tuition, the guaranteed return of prewar jobs, and income allowances for those who were unable to find jobs. However, the bulk of the government's reconstruction effort was geared towards bolstering exports and improving Canada's foreign exchange position. Insofar as the production of domestic goods was limited and the amount of foreign currency to import products in short supply, consumer demand was regarded as a potential source of instability that might drive up prices and wage demands without creating employment. Consumers were urged to exercises prudence and self restraint, moderate demands. and defer spending until such time as the Canadian economy could supply their wants.

In this context, when the supply of domestic goods continued to be outweighed by demand, "know how" and "good buymanship" were celebrated as housewife's "best allies" 10 offset the shrinking dollar and counter the prospect of inflation. In numerous articles written for Saturday Night and Maclean's, women's section columnist Lillian Millar urged women to do without, to question every expense and, when they did have to buy, to shop wisely. Insofar as "financial difficulties in the home inevitably bring demands for higher wages which in turn often result in strikes and labour unrest ... the peace and prosperity of the nation" were seen to hinge on "whether or not personal finances could be put on a sound financial basis." Limiting demand would limit inflation; limiting inflation would limit class strife.

Typically, experts proposed three strategies for dealing with rising prices: thrift, "know-how" and united action. The "housewifely arts," "good buymanship" and above all mastery of the 
family finances through successful budgeting would provide "peace of mind...a sense of security...[and] the thrill of satisfaction which achievement brings."12 Needless buying was discouraged and prudence emphasized in numerous articles. "With so much at stake, no one can afford to buy carelessly or thoughtlessly," 13 admonished Millar. Every purchase was to be scrutinized and shoppers were advised to ask themselves: "Do you need it? Can you afford it?" and "Can you make it or repair it yourself?" Moreover, a higher income was no guarantee of success: no malter how large the income might be, it would not buy everything one might need or desire. As one expert, described as the "veteran of 30,000 family plans," reported: "The most difficult case I ever had was that of a family of two who could not keep out of the red on an income of $\$ 75,000$ a year." 14 Instead, success or failure in managing family finances was seen to depend upon "the amount of thought and effort which is given to make the dollars buy the most comfort and happiness." 15

Education and united effort were also important. Millar, for example, felt that government and business were not doing enough to help Canadian families live within their means. A number of initiatives begun during the war had recently ended and Millar suggested that many of these ideas should be resumed to meet the postwar "slate of emergency." Homemakers' courses which had been offered to women in the services might be made more widely available. New brides would benefit from technical training in the various phases of household management and instruction in ways to make their dollars go further. "Remake Centers" established by the Consumer Branch of the Wartime Prices and Trade Board to assist women in restyling old clothing could be re-opened. Canning centers could be established by local governments to allow housewives to buy fresh produce at the best prices and, with the benefit of expert advice and the use of equipment she could not otherwise afford, feed

12 Chatrlaine, March. 1947.

13 Saturday Nigltt. October 26.1916.

14 thid.

15 Chailaine. March, 194 ?. 
her family nutritious, cost effective and convenient meals. Centers for community education and vocational schools could offer instruction in sewing draperies, repairing and re-upholstering furniture, and other aspects of budgeting and practical aid that would help to ease the pressure of rising prices and make limited resources provide higher standards of living.

Efforts like these, which were in essence ameliorative rather than radical, were preferred by many. When a survey of the members of Chatelaine's Consumer Council in October 1947 asked if they approved of buyers' strikes or the picketing of retail stores, sixty-two percent replied "No." The Canadian housewife preferred, according to the magazine, to manage her home "like her pioneer forebears, with only an occasional squawk, keeping her powder dry and her faith in miracles strong."16 Most families, according to the survey, were able to deal with increased food prices by increases in income, the re-allocation of recreation and clothing allowances, and reducing savings, with the money once invested in Victory Bonds and War Savings Certificates now directed towards the food budget. Chatelaine concluded that the Canadian housewife "talks about her price problems a lot, and likes to share her alarms with neighbours and friends" but there was "very little bitterness in their comments." Most felt that, in spite of high prices, Canada was more fortunate than other countries.

Similar attitudes were expressed by the Canadian Association of Consumers (CAC). While certainly not representative of all Canadian women, this organization was formed in the immediate post war period "to develop a more enlightened opinion on economic affairs and consumer interests, and to express this opinion in such a way as 10 benefit the home, the community and the nation." 17 "The war and its aftermath of problems [had]...awakened Canadian women to a new sense of their responsibilities and of their possibilities, both as homemakers and as citizens"18 explained Mrs. Walton, a founding member who would later become president of the CAC. Early initiatives undertaken by the CAC included briefs to the

16 Chatelaimer. Octoter. 1947.

17 ciled ie Sulunlay Nighr. Novernber I. 1947.

18 Sistunday Nighi, November 1, 1947. 
House of Commons Special Committee on Prices discussing the needs of the home and the family, and a number of successful lobbying efforts to maintain adequate supplies of citrus fruit, to control butter prices during the winter months, and to temporarily lift an embargo on carrots and cabbages during a period of particularly high prices. At the request of the CAC, the Standards Division of the Department of Trade and Commerce had begun drafting new regulations on the labeling of textiles and was examining the issue of labeling mattresses and upholstery, standardizing sizes of children's clothes and the quality of shoes. As a liaison with industry, the CAC had communicated to the Canadian Manufacturers Association dissatisfaction that the belts on many women's dresses were lined with material which could not be washed or dry cleaned, adding to clothing costs.

Clearly, while the CAC was dissatisfied with certain aspects of consumer society, it remained committed to the notion of free enterprise. Refusing "to be stampeded into emotional short term decisions" such as rolling back or freezing prices, the organization believed that the current system had "contributed greatly to one of the highest standards of living in the world and ... provided the greatest measure of protection for consumers generally."19

In general, then, there is evidence of some support for government involvement in the area of educating and informing consumers, but little desire for significant change. Rather than restricting prices, Canadian women would practice thrift to circumvent rising costs. In this context, when the burden and responsibility for making ends meet was laid on the individual family, a balanced household budget was described as the "instrument to obtain what [one] ... want[ed] most out of life."20 It was, moreover, within this period of postwar war uncertainty "the only sound foundation upon which a strong and peaceful nation [could] be built."21

By 1947 the immediate period of crisis had begun to ease.

19 Fond for Though, The Canadian Association for Adult Eillucation. Toronto. Vol. 18. No. 3. Decemter 1957. p. 112. 
Employment was up and consumer expenditure was increasing, from $\$ 14.1$ billion in 1944 to $\$ 17.3$ billion in 1946 and $\$ 18.5$ billion in 1947. 22 Businesses were building new plants, replacing old machinery and working at full capacity. Families, in some instances using their accumulated savings, were buying new homes, automobiles, refrigerators, stoves and the various other consumer durables which they had been denied during the war. As the economy strengthened, Canadians were able to increase their domestic expenditures. Soon Donald Gordon, the Deputy Governor of the Bank of Canada ws able to boast that "[we] drank one third more milk, ate two thirds more pork, rang up two thirds more movie admissions and bought 75\% more new houses in 1948 than in ... 1938 .... We used twice as much gasoline, chewed twice as much gum, bought twice as many refrigerators and ate three times as much ice cream."23

Price controls were gradually lifted, however, rising consumer demand in an environment of still limited supply began to force up prices. Between the war's end and the middle of 1947 the overall cost-of-living index advanced almost 13 percent, food and clothing prices each rose about 17 per cent, and home furnishings rose about 19 per cent. ${ }^{24}$ The average family had $80 \%$ more disposable income to spend in 1948 than in 1938, but certain groups had done better than others. Those earning wages in manufacturing industries had largely kept up with inflation, with an average gain of almost 15 percent, but annuitants, teachers, and many white collar workers had been left behind. 25 In some cases these purchases were made from savings, but in many other instances the acquisition of increasingly available of durable goods as such as cars, refrigerators and stoves was sending Canadians into debt. According to a 1948 Dominion Bureau of Statistics survey, the average Canadian family was now running an annual deficit of $\$ 137$.

22 Rober Bethwell, lan Drumunond, John English, Cunada since 1945: Power, politics, and provincialion, revised edition. (Toronto: University of Tomnto Press, 1989), pp. 68-69.

23 cital in Charlaine, January 1951.

24 Canuda J'rur Book. 1947. p. xxxii

25 lbid. 
While frugality remained an important value, the ideal of austerity was falling by the wayside. In one of her last articles for Saturday Night, entitled "Why budgets don't work" (1948), Millar observed that Canadians had failed to regulate their spending patterns with sufficient discipline. "No budget will work if the family is not willing to base their spending on their income, if they insist on having what they want and then expect the budget to take care of the cost."26 While acknowledging that the imposition of too strict a regime would lead to frayed tempers, she complained that no budget could be expected to "work miracles"27 if families continued to overestimate their incomes and underestimate their expenses. As Millar's rather frustrated tone suggested, expectations and spending patterns were changing.

Three years later, in 195I, an article on the family budget published in Chatelaine revealed the dimensions of changes underway. While careful spending was still deemed necessary if Canadians wanted "to live well in a high priced world," the family budget (now described as "a marvelous bit of household equipment") promised to help make "wishes come true." 28 Moncy management had become a "formula for better living," and the place to begin budgeting was no longer with income but with "wishes." 29 It was now the wish list which, far from being frivolous or dangerous, would provide the incentive to make budgeting work.

\section{The Menzies and The Woods}

From time to time feature stories in Chatelaine examined the spending patterns and lifestyles of typical young Canadian families. ${ }^{30}$ Such articles offer an intriguing glimpse into the repercussions of the

26 Satunday Night. Octoher 9. 1948.

27 lbid.

28 Chatrlaintr. March. 1951.

9 Ibid.

30 There is litle evidence to indieate how particular families were chosen. The decision scems to lave been made at the discretion of the author, and was no doubt made with an eye loward readership. However, as Valerie Korinek has noted. there is evitence of a gap between the audience (Thatlaine targeted in its articles and ife nagazine's achual readership. It is not entirely clear whether this was duc to lie pressure from adventisens and the business side of the pethlicalion to aim for afluent readers, or wheller il was due to the distortions imposed by the authors and editors. who tended to see theit reaters as educated middle class wonien like themselves. 
new consumer orientation for the Canadian family. In 1949 the Menzic family was featured under the heading "Rich on $\$ 40$ a Week." Chatelaine's salute to the Menzies stressed that while anyone could economize grimly, "There's something special about young people like veteran Bill Menzie and his wife Marie, of Hamilton, who are buying their house, raising their children well, and doing it all with deep and salisfying happiness." 31 While some readers might doubt that it was possible to run an attractive charming home on so little, the article insisted that the Menzies proved it could be done and "told us how they do it."

Bill, Marie, their two children (Robbie, 7, and Laila, 9 months) and the family dog Jeepers made do on Bill's wages as a lineman for Bell Telephone which, minus taxes, insurance, and an at source deduction for company bonds, amounted to $\$ 143$ plus an $\$ 11$ family allowance cheque for a total family income of $\$ 154$ a month. This amount was made to cover the carrying charges on the house (a small home with an unfinished upstairs in a veteran's housing development), life insurance, coal, gas, lights, groceries, a $\$ 10$ monthly payment on a vacuum cleaner, $\$ 3$ to Laila's pediatrician, and a few miscellaneous expenses such as the daily paper, tobacco, and street car fare. But behind these "cold figures," Chatelaine assured its readers, "lies a story of devotion and integrity; the story of two fine young people who have found real happiness for themselves by putting the welfare of their family ahead of their own pleasures."

There was, for example, no provision in the budget for clothing. Marie had just bought her first dress in four and a half years. Robbie wore pajamas made by his mother from flour sacking and trimmed with colourful fabric. Bill and Robbie had matching sport shirts made from government surplus cloth. Marie had embroidered their initials on the pockets. Grocery shopping was limited to one trip a week-that way Marie eliminated impulse purchases. The cost of meat was a concern but Marie had "clever ways" of stretching out the week-end roast ("but not day after day 
until the family is tired of it"). Indeed her cooking skills were frequently complimented by the author and her recipe for refrigerator rolls was included with the article.

Both Bill and Marie practiced personal thrift, in part because as children they had grown up on the prairies "when mere survival scemed an end in itself." Marie was part of a clothing exchangewhenever she received a garment she gave another away "so that her closet is not filled with dresses of dubious value that she seldom wears." Bill was finishing the upstairs of the house himself (he had proven to be a very competent carpenter) and rolled his own tobacco. For pleasure there was gardening, pot luck dinners, conversation with friends and sometimes bridge. Marie had rented a room and provided breakfast to a boarder for two weeks to earn the amount necessary to join a book club: $\$ 15$ a year paid "proudly" in advance. She was also something of an artist, working with delicate shells, crocheting and quilting. Embroidered with her own hands on a quilt framed on the wall of the master bedroom was a poem, part of which read:

Let me grow lovely growing old So many old things do

Laces and ivory and gold And silks need not be new...

Chatelaine concluded that these words were the key to the philosophy the Menzies lived every day. Although Bill and Marie may have passed up a lot of things, they had "not "sacrificed", because in their own minds they do not consider anything they have given up a sacrifice." They had been more than repaid by the joys of home ownership and family life.

Five years later the spotlight was focused on another family: Russell and Josephine (Russ and Joie) Woods who were, unfortunately, "in trouble trying to make $\$ 300$ a month cover upkeep on two children, a new bungalow, a bigger car than they should have bought and a rash payment on a TV set."32 The Woods family was the subject of a series of three articles over the course of a year 
written by an expert budget advisor sent by Chaselaine to "help this family make both ends meet."

While the Menzies were described as "special", the Woods were presented as "a family with a universal problem" striving "to participate in Canada's climb toward a higher standard of living." The author's assignment was "to be a budget experiment with a real family... to see if all the precepts of smart buying and management can actually work out well in real life."

Russ Woods was a music teacher in the Windsor public system earning what budget expert, Sid Margolius, described as a fairly typical white-collar salary of $\$ 4,450$. After deductions for insurances, pension, taxes and Patriotic Fund, his take home pay was $\$ 300$ a month (almost double Bill Menzies wages three years earlier). Although both the Menzies and the Woods had mortgages on their homes and bought appliances on the installment plan, the Menzies were presented as skilled in making-do and practiced in self-denial and self-discipline. By comparison, the Woods were adrift in the world of consumer goods and easy credit, irresponsible in their money management, and prone to impulsive purchases.

At the outset of the story, it seemed that Russ rather than Joie was to blame for the family's straightened circumstances. When Russ went out to test drive a small $\$ 500 \mathrm{car}$, he returned with a $\$ 1,400$ Pontiac and a $6 \%$ debt to the Teachers' Credit Union. When Russ found the builders using cheap paint on the house, he told them that he would rather they left the walls bare. When they did, Russ had to buy paint. A few years earlier Russ had "television fever" and bought a reconditioned set for $\$ 25$ down. He and Joie had second thoughts about the purchase but were unable to cancel the contract. The sales manager allowed them to reapply the down payment towards a less expensive radio-phonograph; now the large walnut console occupying a corner of the living room was already broken.

Joie was described as "a brave and expert practitioner of the penny-stretching arts," but the details given of her homemaking efforts suggested limited skills, particularly in light of Marie 
Menzie's accomplishments. Joie, for example, specialized in cooking what the family called "conglomerations." The night before the interview, she had served sausage meat creamed with corn meal. She reported that the "children and Russ loved it," but Chatelaine did not publish the recipe. Joie also sewed, recently she had made-over several old dresses into clothes for her two sons. Without belabouring the point, a family with a child-like inability to control impulse spending, that dressed its sons in made-over women's dresses, and enjoyed eating mush, needed help.

The expert Chatelaine brought in was Sid Margolius, the author of the best selling How to Buy More With Your Money. ${ }^{33} \mathrm{He}$ insisted that the young family start with accurate record kceping and a long range plan. Giving up the car was a subject of discussion, but it was decided that the family would use it carefully and Russ would learn to do some of the servicing himself. The overall goal was to pay down their debts and begin to develop a cash reserve for replacements and repairs. Margolius emphasized the importance of planned spending. Clothing, for example, could be bought at late season sales and clearances. Food could be bought in bulk and canned or frozen vegetables and fruits could be substituted for fresh. Margolius also insisted that the Woods set aside small amounts of cash every month towards furniture and landscaping, "otherwise you'll rebel sooner or later." Margolius described the budget as a muscle: the more it is used, the more effective it becomes. His advise emphasized buying well rather than paying down the mortgage or increasing savings. The problem the Woods faced, was not insufficient income, but insufficient "muscle," experience and knowledge. The solution was not to stop spending, but to plan purchases more carefully, taking advantage of sales, buying in bulk. and keeping installment payments to a minimum.

Although magazine readers had "saluted" the Menzies, they were described as "pulling for" the Woods and returned periodically to see how the family was making out. ${ }^{34}$ By September the family

33 Korineh. p. 289.

34 Korinek noted that not everyone was suppontive of the young fantly. Several reaters wrote Charelaine oljecting to the fanily's spendihrift ways and their inability to function on what many considered an ahove average annual income, see Karinek, pp. 290.291. 
was one member larger (Tim was horn in May), and virtually debt free. The budgeting techniques had helped, but so had the raise Russ had received at the beginning of the school year. Russ had also increased the family income by teaching night school, tutoring and finding some paying passengers for the car. The cash reserve stood at $\$ 64.50$ after paying out for Tim's birth and several appliance repairs. In the second year of planned financing Margolius predicted that the Woods would have few debt payments and would soon be operating on a "pay-as-you-go" basis.

A final report in December of 1954 revealed how the couple had "found new values, new purpose and a new security" through budgeting. Once "baffled", "frustrated", "impatient" and "unsure of themselves", they now had definite aims. "Before we knew what we wanted to do, now we know how to do it" explained Joie. Moreover, they were able to increase their allotment for new appliances and furniture ahead of schedule. Joie, now described as "the family purchasing agent," suggested in order the following acquisitions: an electric floor polisher, a new rug for the living room and an electric clothes dryer. After making a thorough study of a particular field of merchandise, she would determine what type and model to buy and was now described as "an unusually expert shopper" who believed "quite rightly... that home management requires as much skill and thought as business management."

Condensed in the stories of the Menzies and the Woods were the transitions many Canadian families were experiencing. If the Menzie's life epitomized the austerity of the immediate post-war era, the Woods' reflected many of the new developments, particularly the expansion of credit and the redefinition of the roles of various family members. Marie, a wonderful cook. creative homemaker, artist, and pay-as-you-go book club member had metamorphosed to Joie, a "purchasing agent" whose homemaking specialties were dinner-time "conglomerations" and a thoughtful purchasing plan. Similarly, air force veteran Bill had become wage earner Russ. The self-sufficient family marked by an all round competence and held up as a model to 
others, had been replaced, at least in the pages of Chatelaine by one of youthful inexperience, struggling in a new world of credit and consumer purchasing and dependent on expert advice.

By 1954 high and rising levels of domestic consumer demands was becoming an increasingly important stimulus to the continued growth of the Canadian economy. ${ }^{35}$ Canadian consumers were widely credited with staving off a recession that year ${ }^{36}$ and consumer optimism was deemed to have a "healthy influence" on the economy, closing the gap in national expenditures after government and business had retrenched. Looking ahead, an editorial in Canadian Business Magazine concluded: "Let's hope Mr. and Mrs. Consumer keep up the good work."

By 1956 the average Canadian family owed over $12 \%$ of its total income, up from $3.1 \%$ in 1943 and paid out $\$ 135$ a year in interest charges. ${ }^{38}$ The average per capita installment debt had increased threefold since 1942. The biggest credit users were young middle income families like the Woods who typically bought far more on installment than poor families. In this age group it was not unusual to find that at least $48 \%$ of income tied up in mortgage and installment payments. ${ }^{39}$ The problem was not so much wages, which had generally kept pace with rising prices, but the dramatic increase in new opportunities for consumption. In 1957 Procter \& Gamble reported that more than half of it current sales volume came from products which had not existed in 1945. For General Foods the figure was 36 per cent; and for the St. Regis Paper Company, 25 per cent. In the same year David Sarnoff, chairman of the board of R.C.A., noted that " 80 percent of the products we are now selling did not exist ten years ago." In 1958 the president of the National Biscuit Company pointed out that 75 percent of food volume was in products which had not existed twelve years before. ${ }^{40}$

35 Canada Year Hook, 19.4, p. xi.

36 Chavelaine, May. 1958. Castade Yrar Book, 1955.

37 Conndian Business, (Ktonher. 1954, p. 18.

38 Chatelaine, January, 1956. 
Various forms of credit were critical to support rising standards of living under these circumstances, allowing as many Canadians as possible to participate in the expanding world of consumer goods. In this sense credit could be regarded as a valuable tool in building a household, allowing young families to purchase items as needed or to take advantage of special sales. In recognition of these changes, Chatelaine articles advising "How to Borrow Wisely" (1951)41 were giving way to those asking "How much money should your family owe?" $(1956)^{42}$ Still, the nature of Canadian consumer expenditures, on items that would have been unavailable or regarded as luxuries rather than necessities a generation ago, as well as the unprecedented levels of indebtedness, was causing concern (see accompanying chart CANADIAN DEBT RATIOS, 1940 to 1956). ${ }^{43}$ Food for Thought, Canada's magazine of adult education, noted: "Those of us who are now in our forties are often sharply aware of a greal gulf between our thinking and that of young people in their twenties. Older Canadians can remember the standards of their childhood; thrift, hard work, 'pay as you go'... 'Enjoy while you pay' is the new slogan...In war-time, we are expected to 'do without' as a patriotic duty; and in peace-time to buy even more than we need or want, for the same reason! ..."44

41 Chorelolne. February. 1951.

42 Choleldine, January, 1956.

41 Fictional stories such as that of Sheila (ooper ("the wife who expected too mach") and het family, forced into banknupey when her lusband resorted to finance companies to keep up the pretensions of middle class life. presenticd a cleas warning to those who failed to use credis wisely

4 Food For Though. Decenter 1957. p. 107. 109. 


\section{CANADIAN DEBT RATIOS, 1940 to 195645}
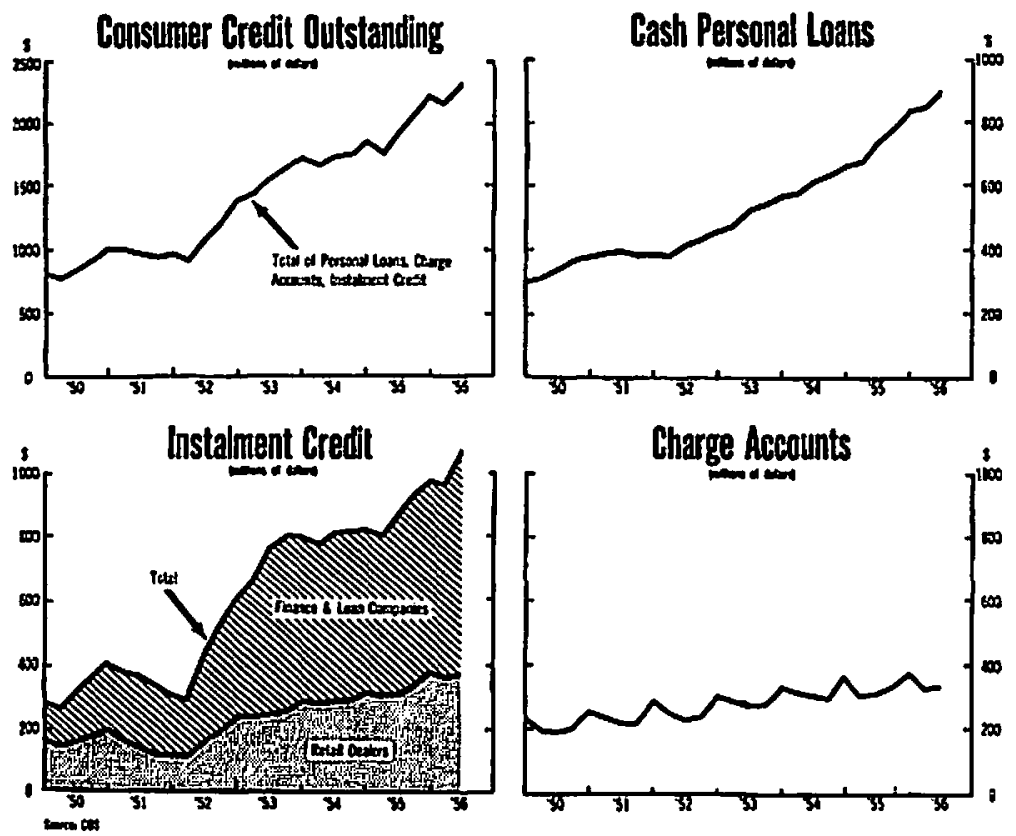

45 Conadian Business. December 1956. Contumer credil usage was partially conirolled until 1952. 
The move towards a sociely defined by its consumption practices saw increasing emphasis placed on the role of the wife as the family's primary spender. A review of advertisements in Maclean's from 1939 to 1950 , conducted by Susan Bland, revealed that the preponderance of advertising was directed toward women and that the majority of those ads appealed to the women in her role as homemaker, promising to remove drudgery from house work, save time and money, and open the door to a new world of discovery and fulfillment though commodities. ${ }^{46}$ In a 1950 article for Maclean's, Margolius observed that "one of the biggest news stories of the decade and one you won't find on the financial page [is that] ... more women are handling family finances than ever before and experts say they make a better job of it than their husbands." ${ }^{\text {47 }}$ Many of the financial experts Margolius consulted offered testimonials to women's financial acumen. "Rather than being naive the average women is actually more experienced in handling money than her husband. ${ }^{248}$ Women were described as being less sentimental about money than men. They were credited with doing anywhere from 80 to 90 per cent of the family purchasing and their experiences had made them "sharp." rates and were persistent in their pursuit of financial goals. Pride never got in their way of good business sense. In investing men were more inclined to seek excitement; women a steady income.

Although there was a certain reluctance on the part of husbands to Iurn financial affairs over to wives, Margolius was quick to offer the needed reassurance:

Some male diehards may grumble that men should never have started all this by giving women the vole. But...rather than resigning any male prerogatives I feel like the chairman of the board. As for womanly extravagances, 1 find my wife is definitely tighter with cash now that she

\$6 Susan Bland, "Henriets the Homenalker, and 'Rosie the Riv ener": Images of Woncen in Adventising in Mlaclean's Magazine, 1939.50" in Atlantis 8, Spring 1983.

47 Maciean's Magazise. Octoher I. 1950. pp. 12.13. 52. 
has charge of it than when I doled it out to her. Then, what I gave her she spent. Now ... I can't get my wife to part with a dollar..$^{50}$

Husbands like Russ Woods were frequently portrayed as less than competent shoppers, unlikely to "feel, pull, rub, squeeze, stretch, press and smell"5l the merchandise or to comparison shop. Increasingly wage earning was gendered male, and expertise in consumption and spending gendered female. On the other hand, many articles were quick to reassure both men and women that traditional family structures could be preserved by presenting these patterns as administrative rather than fundamental changes.

Increasing awareness of the collective impact of the "housewifely dollar" brought renewed attention to the CAC. ${ }^{52}$ As a lengthy feature in Canadian Business Magazine observed, in "the early days businessmen regarded CAC as a group of overly enthusiastic women who were out to make life difficult for them. Today ... CAC has been successful in divorcing itself from the "lunatic fringe" and communist-front troublemakers" and had become "a power not to be dismissed lightly by government or industry."53 Now perceived as, literally, buying into the system, Canadian women and the CAC found themselves celebrated by business.

\section{The Roses}

In 1962 Chatelaine editors selected a new "typical" Canadian family (income $\$ 4,500$, two children) as the subject of a feature story: " I0I Ways to Save Money-and look better, dress better, eat better and live betler." 54 While Chatelaine's previous profiles tended to keep the focus on home and family, the bulk of this feature (13 of 16 pages) used the Roses to showcase expert recommendations for saving, grouped under such captions as "How to Eat Better and 
Save", "See You Can Be Your Own Best Hairdresser and Save", "Have the Furniture You Really Want in Five Years and Save", etc...

Before meeting with Chatclaine, Stan and Rita already practiced certain economies and were proud of their home management skills. They had saved a down payment when Rita was working, before starting a family, and, as a matter of principle had agreed to postpone future purchases until they could pay cash. "We're happier when we know we don't owe anything" Rita explained, "and we don't mind waiting for the things we'd like to have. We don't want many luxuries." In practice this meant that they ate meals in the kitchen while the dining area sat empty, and listened to "semi-classical" records bought at low cost through a record club on a standard portable player while looking forward to a owning a high fidelity phonograph "some day." Family allowance cheques went directly into a trust savings account paying $41 / 2 \%$.

Compared with Marie and Joie, Rita was less a producer or a purchasing agent than a passive vehicle for Chatelaine to demonstrate ideas that would help Canadians lead less expensive but considerably more fashionable lives. For example, Rita had come to rely on convenience foods as a working wife. Chatelaine redirected her menus towards more time intensive and less costly dishes. The recipes featured in the article were all devised by Chatelaine and professionally photographed in the test kitchen.

Other recommendations were far from lavish. Rita's beauty make-over began with six cuts a year at a top salon (because "a good cut is worth every penny") but would be maintained with home permanents and the setting and styling techniques demonstrated by the magazine's beauty editor. Rita's new wardrobe consisted of made-over garments, transformed into smart and useful outfits by Rita herself with the aid of Simplicity and Vogue palterns. One of the grealest differences between the previous stories and this one was the increased number of choices available to the Roses and Chatelaine's breathless sense of excitement about these opportunities. For 
example, it was possible for Rita to make a pale blue duster over into a new party dress because she already had two light weight coats. The family could gear their expenditures toward an ideal furniture plan because they were already setting aside $\$ 200$ annually for furnishings. Their tive year acquisition list, which began with an extension dining table and two chairs in 1962 and concluded with framed prints, plants and bunching tables in 1966, indicated a level of detail and long term commitment to spending significantly beyond that contemplated by the earlier families.

Many of Chatelaine's recommended ways to save now involved spending. For example, tips included the advice that bills should be paid by cash to avoid cheque charges; that a two storey home on a simple foundation was more economical than the same square footage in a bungalow plan; that season tickets were less expensive than individual tickets if one expected to attend recreational events regularly; that consumers should compare the price of repairs with the price of replacement because some articles had dropped in price in recent years while repair charges had increased. Clearly, the focus had shifted from helping the consumer economize to helping the consumer make choices. The challenge was no longer to live within limited means, but to improve one's overall standard of living by planned and thoughtful spending.

Increasingly Canadians needed information about the alternatives available to them. By 1957 Iwenty to 25,000 copies of the American publication Consumer Repor/ were being sold on Canadian newsstands each month, along with over 17,000 subscriptions. 55 In 1962 the $\mathrm{CAC}$ added product testing to its mandate and began to publish results in its Bulletin. Chatelaine had been awarding its "Seal of Approval" to certain products for many years; however the seal began to be featured more prominently, both within the magazine and on product packaging in the late 1950s, certifying that the product had been tested by the Chatelaine Institute and found worthy. In general, magazine articles explaining "how to budget" were 
disappearing, replaced by those explaining how to spend. "Should a dryer be your next appliance?" asked Chatelaine in April of 1959. Other features examined the merits of different brands and styles of electric irons and flatware.

Thrift was less a matter of not spending, than of spending wisely. In 1962 Household Finance of Canada published a 36 page booklet discussing "Your Shopping Dollar", one in a series of money management manuals. "You, the consumer, control the marketplace" Canadians were told. "Your decisions-to buy or not to buy certain goods and services...when and where to buy them...to pay with cash or credil-make you the most important single factor which determines the success of failure of our economy." were encouraged to shop "intelligently" by defining their values and goals, knowing their requirements and by developing a personal buying guide for purchases they planned to make in the future by collecting articles, advertisements and consumer information from various product rating services. "Responsible consumership" the company assured its readers, was "a goal that can be reached by every shopper. ${ }^{.57}$

The publication concluded with a check list to help shoppers evaluate their shopping skills. Consumers who could comfortably answer "Yes" to such questions as: "Is your spending an expression of your individual and family values and goals?", "Are you in the habit of using a well-planned shopping list to be sure you get the things you need and want?", "Do you compare prices and quality of various items before you buy?" and "Are you using your consumer power effectively in the part you play in our national economy?" were, in effect, given permission to go ahead and spend. There was no need to make-do if one followed the rules and spent wisely.

\section{Conclusions}

In The Vertical Mosaic(1965) John Porter noted the prevalence

56 Jour Shopping Dollar, Household Finance. Tomnto and Chicago, 1962. p.2 57 lbid. p. 33. 
in Canada of an idealized "image of a middle level classlessness in which there is a general uniformity of possessions." $\$ 8$ This image, he proposed, was primarily concerned with the consumption of commodities which postwar affluence seemed to have made available to "everybody, except, perhaps, a small group of the permanently poor at the bottom" of society. ${ }^{59}$ Porter observed that the American notion of a standard package of goods synonymous with the middle class way of life was also widely held by Canadians, a fact which he altributed to modern advertising and the spread of American consumers" magazines, "devoted to the task of constructing the ideal way of life through articles on child rearing, homemaking, sexual behaviour, health, sports, and hobbies."60 In reality, the Canadian middle income lay at a lower income range than that in the United States. Porter calculated that the America pattern of living, without the aid of gifts, would require an income of $\$ 8,000$ a year-an income level which in the middle 1950s included at most no more than $10 \%$ of Canadian families. That is, the American vision of the standard middle class package would almost certainly not be available to families with incomes of less than $\$ 4,000$, which constituted $54 \%$ of Canadians in 1955 . The disparity between the limits of income and this image of what constituted a normal home life meant that suburban society would be, from the outset, a society under pressure. ${ }^{61}$

Of all the commodities included in the standard package, the single family detached home was the most costly. Doug Owram has discussed this home and the suburban neighborhood in which it most typically could be found as the epitome of the domestic ideal in an era that revered the family and the child. ${ }^{62}$ But the suburban home was also a commodity, built to sell at a profit. After 1954, most suburban housing was mass produced by large, integrated developers

58 Jolan Porter. The Vertical Mosair (Totonto: University of Tononto Press. 1965). p. 4.

59 Jbid.

60 Jbid.p 129.

61 Valeric Korinek omenes that a similar phenomenon was present in Chatelaine which regarded "middle-class ideals as the norm to which everyone should and did aspire" and generally ained its editorial copy as well as its adrertising lowands an idealized audience that was prexumxd to be nome aflucent. urbanizel ind soplisticated than the publication's actual readership. Korinek. pp. 65 to 70.275.

62 Owram. Hom at the Right Tiver, p. 60. 
along quasi-industrialized lines: large areas of raw land were assembled, cleared and subdivided; trades were organized to complete their task in rapid succession; prefabricated parts were used whenever possible to reduce time and labour costs; and a full range of advertising and sales techniques were brought to bear on the market in order to move product as expeditiously as possible.

While the "white-picket-fence ideal" 63 was quickly embraced as the centerpiece of Canada's drive to domesticity, the purchase price required to make this dream real had the initial effect of making families poor. ${ }^{64}$ As Canadian sociologist S. D. Clark observed, those who moved to the suburbs were typically young families with no substantial savings and only modest incomes. ${ }^{65}$ To finance the down payment on a house and to secure even minimal furnishings these families were required to borrow money, to assume heavy mortgage obligations, and to take on installment payments. Although the purchase of a new suburban home was usually not ruinous, it marked the beginning of the commitment to an ongoing series of expenditures and a long term financial burden. Intriguingly, Clark observed that the majority bought up to or slightly beyond what they could afford. Those who could afford more than the down payment required in any particular area tended to look elsewhere. ${ }^{66}$ In short, Clark suggested that the overall effect of buying a new home was a higher standard of housing but a lowered standard of living. In light of Clark's analysis, the sacrifices the three Chatelaine families made in food budgets, entertainment choices, clothing expenditures and overall financial freedom were fairly typical. Participating in the suburban dream involved young Canadian families in financial circumstances that were largely beyond their previous experiences and at odds with their traditional values towards debt. And yet, the full package of goods was beyond their means without it. 


\section{Percentage of homes}

\begin{tabular}{lccc} 
Equipment & 1963 & 1951 & 1941 \\
Refrigerator & 94 & 48 & 21 \\
Telephone & 87 & 60 & 40 \\
Radio & 96 & 93 & 78 \\
Automobile, one or more & 73 & 43 & 37 \\
Television set & 90 & - & - \\
Vacuum clcaner & 72 & 42 & 24 \\
Washing machine & 87 & 74 & - \\
Phonograph & 54 & - & - \\
Freezer & 18 & - & - \\
\multicolumn{4}{c}{ PERCENTAGE OF HOMES WITH GIVEN } \\
\multicolumn{4}{c}{ FACILITIES AND EQUIPMENT }
\end{tabular}

Gradually, through the 1950s and 1960s, wages and salaries rose and personal disposable income increased. ${ }^{68}$ Whether financed through cash flow and careful budgeting or installment debt, Canadians like the Roses were increasingly able to purchase items which had been deemed "luxuries" or were even unknown fifteen years earlier. By 1963, ninety-four per cent of households had refrigerators, eighty-seven per cent automatic or electric washing machines and ninety per cent television sets (see the accompanying chart PERCENTAGE OF HOMES WITH GIVEN FACILITIES AND EQUIPMENT). ${ }^{69}$ As a whole that year, Canadians spent $\$ 20$ billion on consumer goods and services. However, to accomplish this, they had in less than 10 years doubled their charge account and installment debt to department stores and increased debts to banks for personal loans three and one half times. The total outstanding consumer credit charges (including finance company and bank loans, consumer credit and home improvement loans) reached new peak of

67 Frederick Elkin, The Fanth in Canado 1Oxlawa: Canadian Conference on the Family, 19641. p. 81. and to lasve less aval lable for gifts, taxes. security, and miscellaneous comtuxdities and senvices, however. sandants of tiving were rising for most Canadians.

69 Ibid. p. 85 . 
$\$ 3,664,000,000$, representing a debt of about of $\$ 200$ for every man, women and child in Canada. ${ }^{70}$

Some of the shifts from 1947 to 1962 were clear: The Menzies (1949) bought as little as possible. The Woods (1954) tended to buy impulsively, a trait they were expected to learn to manage by training and self-discipline. In the Roses (1962) case, however, the "purchasing impulse" was directed to "networks of objects,"7l such as the five year plan for home furnishings, comprehensive enough to include artwork and accessories. Similarly, the housewife's personal shopping expanded from a single dress to a wardrobe restyled with the aid of store-bought patterns and a new haircut maintained with home permanent kits. The chain of purchasing had been extended in terms of the number of goods involved, the timeframe needed to complete the planned purchases, and the ongoing spending required to avoid obsolescence that was implied in the article's emphasis on an up-to-date haircut and wardrobe. The process was quite different from both the slow, selective acquisition of single objects and the impulsive shopping described in the earlier situations. The advice offered by Chatelaine had shifted from how to manage without money, to how to manage money, to how to save money by spending money.

The systematic expansion and generalization of consumer practices was accompanied by a change in emphasis from the reliance on self to the reliance on expertise; and a shift from inner character, personal ability and non-pecuniary values to appearances carefully assembled through the judicious purchase of goods and services. The story of the Menzie family had emphasized their strength of character and innate skills. Some mention was made of new purchases, but more attention was given to Marie's abilities as an artist, seamstress, and cook. The admiration of the author for her subjects was clear throughout the article. The Woods were younger, adrift in new world of consumer goods, unable to manage their finances, and considerably less capable. However, as they gained control of their financial situation, they were perceived to have gained strength in 
other areas of life (e.g. Russ learned to change the oil himself). They were encouraged to take on personal responsibility, as were Chatelaine readers, who were told that budgets should be tailor-made to suit each family. A paternalistic budgeting expert played a prominent role in the article, taking up one-third to one-half of the text. The Woods were a transitional family: the onus to control spending remained with the family, but it was necessary, in effect, for them to serve a period of apprenticeship. By comparison, the Roses seemed to have been selected less for who they were than for who they had the potential to become under the transforming influence of Chatelaine's team of experts. Meanwhile, as the family became increasingly passive the magazine became more visible as the arbiter of appropriate expenditures.

On the other hand, Rita Rose seemed to have a certain freedom to remake herself and her home that her predecessors lacked. In part this was due to increasing affluence. However, insofar as Chatelaine showed that the key elements of persona and home life could be purchased in the marketplace, identity seemed to have become less fixed and less internalized: character had given way to personality. ${ }^{72}$

Finally, there are significant differences in the gendering of consumption over time. The 1947 story presented both husband and wife as wage earners and consumers. At the outset of the 1952 article, the husband earned as well as consumed, albeit in a rather incompetent fashion. In the course of the story, the husband-asconsumer was marginalized and pushed out the home, now working evenings as well as days to finance purchases made by a wife and mother who had developed into a consumption expert. By 1963 the husband was all but absent, earning the wages that made a "typical" Canadian lifestyle possible. The boundary between domestic and personal expenditure on the part of the wife/homemaker has blurred and, although the magazine does not hesitate to dispense advise as to how spending practices could be improved upon, it takes her

72 American historian Warren Susman also ideatifies this as ore of the key marhers in the Iransition froun a puritan to a consumer culfure. See Chapter 14. " Personality' and like Mlaking of Twentieth Cenlury Culture" in Warren Susman, Culium as Hisoon INew York: Pantheron. 1984). 
participation in the marketplace for granted.

While the size of the shift from managing scarcity to managing relative abundance and from budgeting to buying should not be exaggerated, the origins of many trends we associate today with consumer culture were still missing in the late 1940s but apparent in the early 1960s. In these years Canadians learned to negotiate a series of new trade-offs between saving and spending that opened the door to expenditures on items that would once have been considered non-essential, providing that these expenses were undertaken with caution and calculation, involving, for example, comparison shopping, expert guidance, or a long term budget.

Ultimately, reading about the experiences of these families, presented as typical in the pages of Chatelaine, helped to legitimize new attitudes towards consumption. Whether each "author was an 'expert' by profession or from research and interviews," presented, with compelling authority, images of a new way of life and instructions on how to achieve it. As the resistance to spending was overcome and imperatives to spend were given voice, the move toward an ethos of consumption was clearly underway.

73 Korinch. p. 274. 